\title{
PENGARUH MODEL PEMBELAJARAN KOOPERATIF TIPE GROUP INVESTIGATION (GI) TERHADAP HASIL BELAJAR FISIKA DITINJAU DARI GAYA BELAJAR SISWA
}

\author{
Siska Widiawati*, Hikmawati, Wahyudi \\ Program Studi Pendidikan Fisika, Universitas Mataram \\ *Email: siskawidiawati059@gmail.com
}

\begin{abstract}
This research is aimed to tests (1) the effect of cooperative model learning in group investigation (GI) type toward the students learning physics result observed from students' learning technique, (2) the effect of students learning strategy toward students' learning physics result, (3) the interaction of cooperative model learning in group investigation (GI) type toward students learning strategy toward students learning physics result. This type of research is quasi experiment with factorial design $2 \times 3$ research program. The population of this research is all of the XI IPA class of SMAN 8 Mataram. The source sample of this research is using cluster random sampling technique. Hence, XI IPA 3 class has been chosen as experiment class and XI IPA 5 as control class. The collecting data of students' learning result done by using multiple choice questions with 74.1 mean score of experiment class and 65,4 mean score for control class and measure students' learning strategy by giving learning strategy questionnaire. Hypothesis tested using ANAVA two ways with 5\% significant standard. The result of first hypothesis shows that 22,85 for $f_{\text {count }}$ that bigger than 4,03 $f_{\text {table }}$ means that there is a effect of cooperative model learning in group investigation (GI) type toward students' learning physics result. While the second hypothesis shows that 25,05 $f_{\text {count }}$ bigger than 4,03 $f_{\text {table }}$ there is a effect of cooperative model learning in group investigation (GI) type toward students' learning outcome. Last, hypothesis shows that 4,57 $f_{\text {count }}$ bigger than 3,18 $f_{\text {table }}$ means there is an the interaction of cooperative model learning in group investigation (GI) type toward students' learning strategy toword students realning physics result.
\end{abstract}

Keywords: Cooperative learning, Group Investigation, Learning outcome.

\section{PENDAHULUAN}

Pendidikan merupakan salah satu aspek pembangunan yang harus dikembangkan disamping aspek lainnya. Melalui pendidikan diharapkan bangsa ini dapat mengikuti perkembangan dalam bidang sains dan teknologi yang semakin berkembang. Beberapa upaya telah dilakukan oleh pemerintah untuk meningkatkan mutu pendidikan, diantaranya penyempurnaan kurikulum. Mulai kurikulum 1994 hingga Kurikulum Tingkat Satuan Pendidikan (KTSP) hingga Kurikulum 2013 (K13) yang mencakup semua mata pelajaran termasuk pelajaran Fisika.

Fisika merupakan salah satu cabang sains yang besar peranannya dalam kehidupan, terlebih di bidang ilmu pengetahuan dan teknologi (IPTEK) yang berkembang dengan pesat saat ini. Fisika tidak hanya memberikan sumbangan yang nyata terhadap perkembangan teknologi melainkan juga mendidik siswa untuk memiliki sikap intelektual dan religi dalam kehidupan. Oleh karena itu siswa dituntut agar mampu menghadapi perubahan dalam segala bidang, bertindak atas dasar pemikiran yang logis, berpikir kritis, kreatif, dan inovatif. Salah satunya yaitu dengan mempelajari Fisika.

Dick and Carey (1996) menyatakan bahwa seorang guru hendaklah mampu mengenal dan mengetahui karakteristik siswa, sebab dengan pemahaman yang baik terhadap karakteristik siswa, guru akan dapat menyesuaikan metode pembelajaran yang digunakannya yang tentunya sangat 
mempengaruhi keberhasilan proses belajar siswa (dalam Halim, 2012). Masalah dalam pembelajaran dapat diatasi dengan penguunaan model pemebalajaran yang tepat oleh guru. Penggunaan model yang tidak tepat berimplikasi pada hasil yang kurang optimal (Gunawan et al., 2017). Selain itu, menurut Suparman (1997) karakteristik dan kemampuan awal siswa sangat mempengaruhi cara belajarnya dan juga mempengaruhi perhatiannya dalam pembelajaran. Oleh sebab itu, dalam proses pembelajaran guru hendaknya mengetahui hal tersebut agar dapat menerapkan cara penyampaian pembelajaran yang menarik bagi siswa sehingga selanjutnya diharapkan akan meningkatkan hasil pembelajaran.

Karakteristik siswa yang dimaksudkan dalam penelitian ini adalah gaya belajar. Nasution (2003) menyebutkan bahwa gaya belajar adalah atau learning style cara bereaksi dan menggunakan perangsangperangsang dalam proses belajar. DePorter, et al. (2001) menyatakan bahwa setiap peserta didik memiliki kecenderungan secara dominan salah satu dari gaya belajar yang dimiliki (dalam Pujani et al., 2013). Berdasarkan modalitas VAK, gaya belajar pada peserta didik dapat dibagi menjadi tiga jenis, yaitu gaya belajar visual (V), gaya belajar auditori (A), dan gaya belajar kinestetika (K). Ketiga jenis gaya belajar tersebut mempengaruhi peserta didik dalam belajar (Pujani, et al., 2013).

Berdasarkan pemaparan di atas, maka guru dalam pembelajaran yang efektif harus banyak memberi kebebasan kepada peserta didik untuk dapat mengamati, belajar, dan mencari konsep masalah secara mandiri. Guru dituntut untuk mendesain suatu model pembelajaran inovatif yang mengarah pada suatu peningkatan hasil belajar yang dicapai oleh siswa, salah satunya yaitu dengan proses belajar gotong royong atau belajar kelompok atau kooperatif. Menurut Vygotsky dalam
Suparmi, et al. (2016) menyatakan bahwa pada pembelajaran kooperatif siswa dihadapkan pada proses berfikir teman sebaya mereka, dengan metode ini tidak hanya membuat hasil belajar terbuka untuk seluruh siswa, tetapi juga membuat proses berfikir siswa lain terbuka untuk seluruh siswa. Menurut Nisrina et al. (2016) odel pembelajaran kooperatif menuntut siswa untuk memecahkan sebuah permasalahan secara kooperatif atau bersama untuk mencapai tujuan bersama dimana setiap anggota kelompok memiliki kemampuan kognitif yang berbeda sehingga dapat meningkatkan penguasaan konsep mereka karena saling bekerjasama.

Tsoi (2004) menyebutkan bahwa pembelajaran kooperatif tipe Group Investigation (GI) merupakan model pembelajaran yang sesuai dengan paradigma konstruktivis, model kooperatif tipe GI memberikan kesempatan seluasluasnya kepada siswa untuk terlibat langsung dan aktif dalam proses pembelajaran mulai dari perencanaan sampai cara mempelajari suatu topik (dalam Tika, et al. 2014).

Group Investigation (GI) merupakan salah satu bentuk pembelajaran kooperatif yng menekankan pada partisipasi dan aktivitas siswa untuk mencari sendiri materi (informasi) pelajaran yang akan dipelajari melalui bahan-bahan yang tersedia. Siswa dilibatkan mulai dari perencanaan, baik dalam menentukan topik maupun cara untuk mempelajari melalui investigasi (Suparmi, et al. 2016).

Model pembelajaran GI ini merupakan salah satu tipe pembelajaran kooperatif yang berorientasi pada siswa. Siswa belajar dalam kelompok-kelompok kecil yang heterogen, belajar bersama, saling membantu, dan berdiskusi menemukan dan menyelesaikan masalah Depdiknas 2005 (dalam Asyhar, et al., 2012). 
Keberhasilan prestasi belajar siswa juga dipengaruhi oleh faktor internal dan eksternal. Faktor internal antara lain; kemampuan awal, motivasi belajar, IQ, minat belajar, gaya belajar, keingintahuan, keaktifan, kreativitas belajar, dan sikap ilmiah siswa. Sedangkan faktor eksternal meliputi model, metode sarana prasarana pembelajaran, serta media pembelajaran.

Menurut Deporter, et al. (2013) dalam 'Ardhuha, et al. (2016) gaya belajar adalah kombinasi dari cara seseorang dalam menyerap informasi, kemudian mengatur informasi, dan mengolah informasi tersebut menjadi bermakna. Hariyanto dan Suyono (2011) menyebutkan terdapat tiga jenis gaya belajar, yang diklasifikasikan berdasarkan kecenderungan dan kecepatan seseorang dalam memproses informasi yaitu: gaya belajar auditif (mendengar), gaya belajar visual (melihat), gaya belajar kinestetik (belajar langsung melalui gerakan, bekerja, menyentuh).

Menurut Gunada et al. (2015) Hasil

Belajar adalah perubahan kemampuan yang diperoleh setelah pelaksanaan kegiatan pembelajaran. Sedangkan menurut Wahyuni et al. (2016) hasil belajar diartikan sebagai proses perubahan tingkah laku pada diri individu berkat adanya interaksi antara individu dan individu dengan lingkungannya. Seseorang setelah mengalami proses belajar akan mengalami perubahan tingkah laku, baik aspek pengetahuannya(kognitif), keterampilannya (psikomotor) maupun aspek sikapnya (afektif).

Hipotesis dalam penelitian ini akan dijelaskan sebagai berikut:

Hipotesis 1

$H_{01}$ : Tidak ada pengaruh model pembelajaran kooperatif tipe Group Investigation (GI) terhadap hasil belajar fisika siswa.

$$
\begin{aligned}
H_{a 1}: & \text { Ada pengaruh model } \\
& \text { pembelajaran kooperatif tipe } \\
& \text { Group Investigation (GI) } \\
& \text { terhadap hasil belajar fisika } \\
& \text { siswa. }
\end{aligned}
$$

Hipotesis 2

$H_{02}$ : Tidak ada pengaruh gaya belajar terhadap hasil belajar fisika siswa.

$H_{a 2}$ : Ada pengaruh gaya belajar terhadap hasil belajar fisika siswa.

Hipotesis 3

$H_{03}$ : Tidak ada interaksi antara model pembelajaran kooperatif tipe Group Investigation (GI) dengan gaya belajar terhadap hasil belajar fisika siswa.

$H_{a 3}$ : Ada interaksi antara model pembelajaran kooperatif tipe Group Investigation (GI) dengan gaya belajar terhadap hasil belajar fisika siswa.

\section{METODE PENELITIAN}

Jenis penelitian yang digunakan adalah kuasi eksperimen dengan desain faktorial $2 \times 3$. Sebelum diberi perlakukan kedua kelompok sampel diberikan tes awal untuk mengukur kondisi awal dan pemberian angket gaya belajar untuk mengetahui gaya belajar siswa.

Selanjutnya kelas eksperimen diberikan perlakuan model pembelajaran kooperatif tipe Group Investigation (GI) dan kelas kontrol diberi perlakuan berupa model pembelajaran konvensional (direct instruction). Sesudah perlakuan, kedua kelas diberikan tes akhir. 
Tabel 1. Rancangan Faktorial 2x3

\begin{tabular}{|c|c|c|c|}
\hline \multirow{2}{*}{$\mathrm{B}$} & \multicolumn{3}{|c|}{ Gaya Belajar (B) } \\
\cline { 2 - 4 } & $\begin{array}{c}\text { Visual } \\
(\mathrm{B} 1)\end{array}$ & $\begin{array}{c}\text { Audio } \\
(\mathrm{B} 2)\end{array}$ & $\begin{array}{c}\text { Kinestetik } \\
(\mathrm{B} 3)\end{array}$ \\
\hline $\begin{array}{c}\text { Group } \\
\text { Investigation } \\
(\mathrm{A} 1)\end{array}$ & $\mathrm{A} 1 \mathrm{~B} 1$ & $\mathrm{~A} 1 \mathrm{~B} 2$ & $\mathrm{~A} 1 \mathrm{~B} 3$ \\
\hline $\begin{array}{c}\text { Konvensional } \\
\left(\mathrm{A}_{2}\right)\end{array}$ & $\mathrm{A} 2 \mathrm{~B} 1$ & $\mathrm{~A} 2 \mathrm{~B} 2$ & $\mathrm{~A} 2 \mathrm{~B} 3$ \\
\hline
\end{tabular}

Dalam penelitian ini terdapat 4 variabel yaitu variabel bebas yaitu model pembelajaran kooperatif tipe Group Investigation (GI), variabel terikat yaitu hasil belajar fisika siswa, variabel moderator yaitu gaya belajar siswa, dan variable kontrol yaitu materi ajar yang diajarkan, guru yang mengajar, dan instrumen penilaian pada kelas eksperimen dan kontrol. Populasi dalam penelitian ini adalah seluruh peserta didik kelas XI IPA di SMAN 8 Mataram tahun ajaran 2017/2018 yang berjumlah 5 kelas. Sampel yang digunakan dipilih dengan menggunakan teknik cluster random sampling, sehingga diperoleh kelas XI IPA 3 sebagai kelas eksperimen dan XI IPA 5 sebagai kelas kontrol.

Instrumen penelitian yang digunakan adalah tes pilihan ganda dengan lima alternatif jawaban untuk hasil belajar fisika siswa dan angket untuk gaya belajar siswa. Setelah diuji validitas, realibilitas, tingkat kesukaran, dan daya beda soal diperoleh 25 soal yang digunakan untuk pilihan ganda dan 25 item soal angket untuk gaya belajar. Uji hipotesis dalam penelitian ini menggunakan analisis varians (anava) dua jalan dengan syarat telah terdistribusi normal dan homogen. Dalam penelitian ini juga digunakan uji lanjut berupa uji Scheffe karena terdapat interaksi antara model yang digunakan dengan gaya belajar terhadap hasil belajar.

\section{HASIL DAN PEMBAHASAN}

Hasil penelitian berupa data kemampuan awal siswa, data gaya belajar, dan data hasil belajar siswa. Data kempuan awal siswa diperoleh dari hasil pemberian tes awal yang diuji homogenitasnya untuk mengetahui apakah kemampuan awal siswa kelas eksperimen dan kelas kontrol itu sama. Berdasarkan uji homogenitas didapatkan bahwa kedua kelas memiliki kemampuan awal yang sama yang artinya data homogen dan terdistribusi normal. Data gaya belajar diperoleh berdasarkan pengisian angket oleh siswa. Untuk data selengkapnya dapat di lihat sebagai berikut:

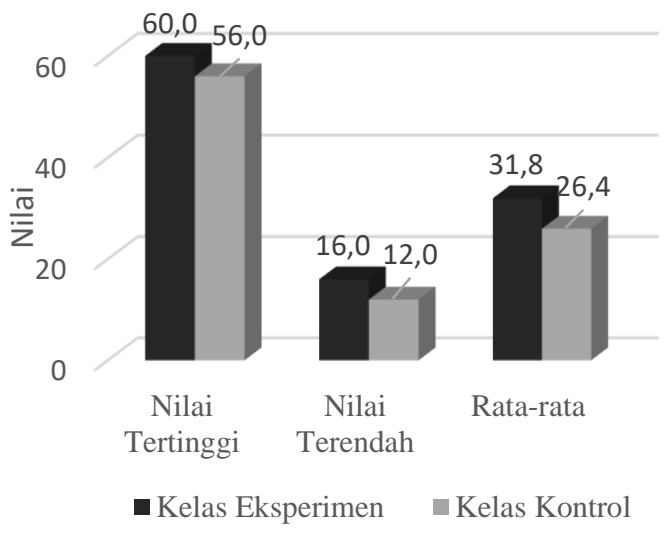

Gambar 1. Hasil Tes Awal pada Kedua Kelompok Sampel

Siswa yang masuk dalam kategori gaya belajar visual, audio dan kinestetik kemudian dikelompokkan berdasarkan nilai hasil belajar yang diperoleh. Hasil analisis angket gaya belajar ditunjukkan pada tabel 2 berikut.

Tabel 2. Hasil Analisis Angket Gaya Belajar

\begin{tabular}{lcc}
\hline & $\begin{array}{c}\text { Kelas } \\
\text { Eksperimen }\end{array}$ & $\begin{array}{c}\text { Kelas } \\
\text { Kontrol }\end{array}$ \\
\hline Jumlah Siswa & 28 & 28 \\
Nilai tertinggi & 96,0 & 92,0 \\
Nilai terendah & 48,0 & 36,0 \\
\hline
\end{tabular}




\begin{tabular}{lcc}
\hline & $\begin{array}{c}\text { Kelas } \\
\text { Eksperimen }\end{array}$ & $\begin{array}{c}\text { Kelas } \\
\text { Kontrol }\end{array}$ \\
\hline Rata-rata nilai gaya belajar visual & 78,0 & 72,4 \\
Rata-rata nilai gaya belajar audio & 77,6 & 47,0 \\
Rata-rata nilai gaya belajar kinestetik & 52,0 & 38,7 \\
Jumlah siswa kategori gaya belajar visual & 14 & 21 \\
Jumlah siswa kategori gaya belajar audio & 10 & 4 \\
Jumlah siswa kategori gaya belajar kinestetik & 4 & 3 \\
\hline
\end{tabular}

Setelah diberi perlakuan, siswa diberikan tes akhir untuk mengetahui pengaruh dari perlakuan yang diberikan. Data hasil tes akhir kelas eksperimen dan kelas kontrol telah diuji homogenitas dan normalitasnya dan disajikan sebagai berikut.

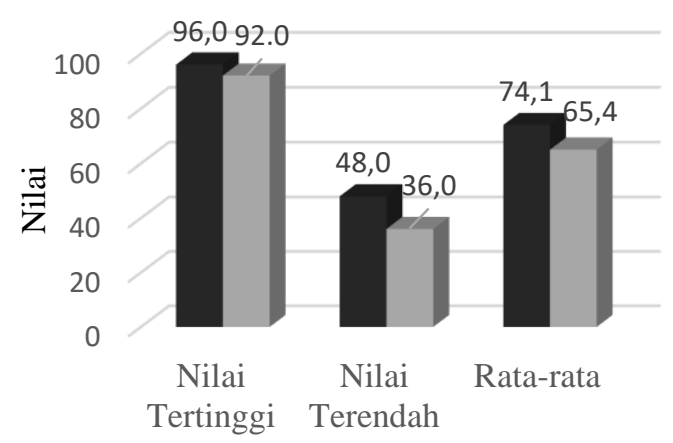

- Kelas Eksperimen Kelas Kontrol

Gambar 2. Hasil Tes Akhir pada Kedua Kelompok Sampel

Selain hasil belajar pada ranah kognitif, diperlihatkan juga hasil belajar ranah afektif dan psikomotor sebagai data penunjang hasil belajar siswa selama proses pembelajaran berlangsung pada kedua kelompok sampel.

Tabel 3. Data Rata-rata Hasil Belajar Ranah Afektif dan Psikomotor pada Kedua Kelompok Sampel

\begin{tabular}{ccc}
\hline Ranah & Eksperimen & Kontrol \\
\hline Afektif & 76,897 & 75,223 \\
Psikomotor & 80,357 & 77,121 \\
\hline
\end{tabular}

Diketahui data adalah homogen dan terdistribusi normal sehingga uji statistik yang digunakan adalah anava dua jalan. Uji anava dua jalan digunakan untuk mengetahui pengaruh model pembelajaran, sikap ilmiah, dan interaksi antara keduanya terhadap hasil belajar fisika siswa. Hasil analisis uji hipotesis menggunakan anava dua jalan dapat dilihat pada tabel 4 .

Tabel 4. Hasil Uji Hipotesis Anava Dua

\begin{tabular}{ccccc}
\multicolumn{5}{c}{ Jalan } \\
\hline Sumber & Fhitung & Ftabel & P & Kesimpulan \\
\hline $\begin{array}{c}\text { Model } \\
\text { (A) }\end{array}$ & 22,85 & 4,03 & 0,05 & $\mathrm{H}_{0}$ Ditolak \\
$\begin{array}{c}\text { Gaya } \\
\text { Belajar } \\
(\mathrm{B})\end{array}$ & 25,05 & 3,18 & 0,05 & $\mathrm{H}_{0}$ Ditolak \\
$\begin{array}{c}\text { Interaksi } \\
(\mathrm{AB})\end{array}$ & 4,57 & 3,18 & 0,05 & $\mathrm{H}_{0}$ Ditolak \\
\hline
\end{tabular}

Hubungan interaksi antara model pembelajaran dan gaya belajar terhadap hasil belajar siswa dapat dilihat pada grafik di bawah.

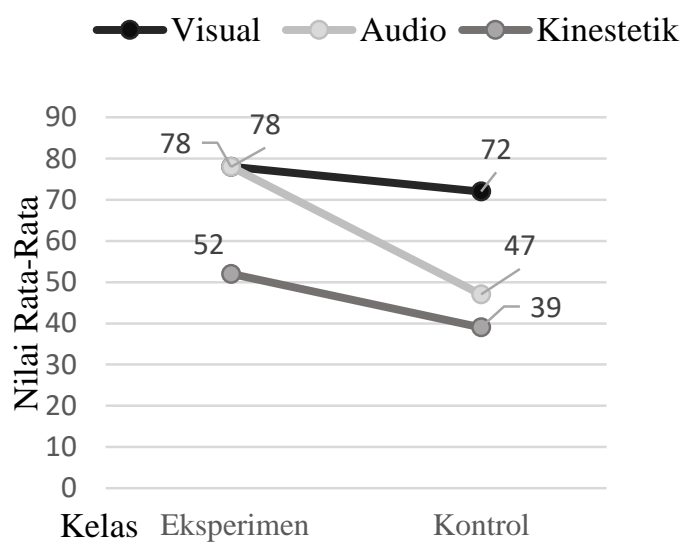

Gambar 3. Interaksi Antara Model Pembelajaran dengan Gaya Belajar Siswa.

Berdasarkan hasil analisis variansi dua jalan dapat diketahui adanya interaksi pengaruh antara model pembelajarann dengan gaya belajar terhadap hasil belajar fisika, selanjutnya dilakukan analisis lanjut dengan menggunakan uji Scheffe. Uji Scheffe digunakan untuk mengetahui lebih 
rinci kelompok mana yang berinteraksi terhadap hasil belajar fisika siswa.

Tabel 4. Perbandingan Jumlah Siswa dan Nilai Rata-Rata untuk Tiap Kelompok

\begin{tabular}{cccc}
\hline \multirow{2}{*}{ Model } & \multicolumn{3}{c}{ Gaya Belajar } \\
\cline { 2 - 4 } & $\mathrm{V}$ & $\mathrm{A}$ & $\mathrm{K}$ \\
\hline GI (1) & $\bar{x}_{11}$ & $\bar{x}_{12}$ & $\bar{x}_{13}=52,0$ \\
& $=78,0$ & $=77,6$ & $n_{13}=4$ \\
& $n_{11}=14$ & $n_{12}=10$ & \\
Konvensi & $\bar{x}_{21}$ & $\bar{x}_{22}$ & $\bar{x}_{23}=38,7$ \\
-onal (2) & $=72,4$ & $=47,0$ & $n_{23}=3$ \\
& $n_{21}=21$ & $n_{22}=4$ & \\
\hline
\end{tabular}

Keterangan:

$\mathrm{n}=$ jumlah siswa, $\bar{x}=$ nilai rata-rata, $\mathrm{V}=$ Visual, $\mathrm{A}$ $=$ Audio, $\mathrm{K}=$ Kinestetik

\section{Hipotesis Pertama}

Berdasarkan hasil penelitian, terlihat ada peningkatan rata-rata nilai tes akhir dari tes awal yang telah dilakukan. Peningkatan rata-rata nilai ini terjadi pada kedua kelas sampel. Pada kelas eksperimen yang diberikan perlakuan model pembelajaran kooperatif tipe group investigation memiliki rata-rata nilai tes akhir 74,1 dan pada kelas kontrol yang diberikan perlakuan pembelajaran konvensional memiliki rata-rata nilai tes akhir sebesar 65,4 . Walaupun keduanya memiliki ratarata nilai yang meningkat tetapi pada kelas yang diterapkan model pembelajaran kooperatif tipe group investigation jauh lebih baik dari pada kelas yang diterapkan model pembelajaran konvensional terbukti dengan perbedaan rata-rata nilai tes akhir pada kedua kelas.

Selain itu, berdasarkan analisis statistik dengan anava dua jalan diperoleh $F_{\text {hitung }}$ untuk hipotesis pertama lebih besar dari pada $F_{\text {tabel }}$ yang nilainya dapat dilihat pada tabel 4. Hasil ini membuktikan bahwa model pembelajarn kooperatif tipe group investigation berpengaruh terhadap hasil belajar fisika siswa sehingga $\mathrm{H}_{01}$ ditolak dan $\mathrm{H}_{\mathrm{a} 1}$ diterima, artinya ada pengaruh model pembelajaran kooperatif tipe group investigation terhadap hasil belajar fisika siswa.

Model Pembelajaran kooperatif tipe group investigation memberika pengaruh positif terhadap hasil belajar baik dalam ranah kognitif, psikomotor maupun afektif sebagaimana terlihat pada tabel 3. Kelas eksperimen dengan penerapan group investigation memiliki rata-rata nilai lebih tinggi dibandingkan kelas kontrol dengan pembelajaran konvensional. Ini menginterpretasikan bahwa kelas dengan penerapan group investigation memiliki kematangan tingkat berpikir lebih unggul, baik $\mathrm{C} 1$ (mengingat) ataupun yang lebih tinggi C6 (mencipta). Keenam domain kognitif dapat dicapai dengan baik dengan adanya sintaks group investigation yaitu memilih topik, merencanakan, menginvestigasi, analisis dan sintesis (menyiapkan laporan), persentasi dan evaluasi.

Hal ini sejalan dengan penelitian yang dilakukan oleh Rajo (2017) dan Wiratana, et al. (2013) yang menyimpulkan bahwa hasil belajar fisika siswa dengan penerapan model pembelajaran kooperatif tipe group investigation lebih baik daripada hasil belajar fisika siswa dengan penerapan pembelajaran konvensional. Selain itu, didukung juga oleh hasil penelitian Rahmatullah, et al. (2017) menyimpulkan bahwa model pembelajaran kooperatif tipe GI berpengaruh terhadap aktivitas dan hasil belajar fisika siswa.

\section{Hipotesis Kedua}

Kemampuan seseorang untuk memahami dan menyerap pelajaran sudah pasti berbeda tingkatnya. Ada yang cepat, sedang dan ada pula yang sangat lambat. Setiap individu tidak hanya belajar dengan kecepatan yang berbeda tetapi juga memproses informasi dengan cara yang berbeda. Karenanya, mereka seringkali harus menempuh cara berbeda untuk bisa 
memahami sebuah informasi atau pelajaran yang sama.

Cara memproses informasi yang diperoleh dikenal dengan istilah gaya belajar. Marsh (2005) menyebutkan bahwa gaya belajar merupakan suatu cara atau sikap yang dilakukan seseorang atau sekelompok orang sebagai pencari penerima, pelajaran yang dibutuhkanya yang dialaminya sendiri dengan mempergunakan alat inderanya. Setiap siswa memiliki gaya belajarnya sendiri, diumpamakan seperti tanda tangan yang khas bagi dirinya sendiri (dalam Hariyanto dan Suyono, 2011).

$\begin{array}{cccc}\text { Gaya belajar } & \text { siswa } & \text { diukur } \\ \text { menggunakan } & \text { angket } & \text { gaya belajar }\end{array}$ kemudian dihitung skornya. Peneliti membagi gaya belajar siswa menjadi tiga kategori yakni visual, audio dan kinestetik. Gaya belajar siswa dikelompokkan berdasarkan skor akhir dari ketiga gaya belajar tersebut yang dominan. Kemudian masing-masing gaya belajar dikelompokkan dengan perolehan nilai tes akhir siswa.

Berdasarkan hasil analisis statistik anava dua jalan didapatkan $F_{\text {hitung }}$ lebih besar dari $\mathrm{F}_{\text {tabel }}$ sehingga $\mathrm{H}_{02}$ ditolak dan $\mathrm{H}_{\mathrm{a} 2}$ diterima yang artinya ada pengaruh gaya belajar terhadap hasil belajar fisika siswa. Pada tabel 4 terlihat siswa dengan gaya belajar visual memiliki rata-rata nilai yang lebih baik dari pada siswa yang dengan gaya belajar audio dan kinestetik. Akan tetapi perbedaan nilai antara gaya belajar visual dengan audio tidak jauh berbeda dibandingkan dengan nilai rata-rata gaya belajar kinestetik. Pada kelas eksperimen dengan model pembelajaran kooperatif tipe group investigation, siswa dengan gaya belajar visual memiliki ratarata nilai hasil belajar sebesar 78,0, sedangkan siswa dengan gaya belajar audio memiliki rata-rata nilai sebesar 77,6 dan siswa dengan gaya belajar kinestetik memiliki rata-rata nilai sebesar 52,0. Pada kelas kontrol dengan model pembelajaran konvensional, siswa dengan gaya belajar visual memiliki rata-rata nilai hasil belajar sebesar 72,4, sedangkan siswa dengan gaya belajar audio memiliki rata-rata nilai sebesar 47 dan siswa dengan gaya belajar kinestetik memiliki rata-rata nilai sebesar 38,7 .

Hal ini membuktikan bahwa gaya belajar berpengaruh terhadap hasil belajar fisika siswa. Walaupun kedua kelas mendapat perlakuan yang berbeda pada penerapan model pembelajaran tetapi siswa dengan gaya belajar visual mendapatkan hasil belajar yang lebih baik dari pada siswa dengan gaya belajar audio dan disusul oleh gaya belajar kinestetik. Hasil penelitian ini sesuai dengan penelitian sebelumnya yang dilakukan oleh 'Ardhuha, et al. (2016) menyatakan bahwa terdapat pengaruh gaya belajar terhadap hasil belajar IPA Fisika siswa. Hal ini juga sejalan dengan penelitian Halim (2012) dalam jurnalnya yang menyatakan bahwa terdapat perbedaan hasil belajar siswa yang mempunyai kecenderungan gaya belajar visual, audio, dan kinestetik.

Teori belajar pemrosesan informasi dimulai dengan menyerap informasi melalui indra kemudian diteruskan di otak dan disimpan. Penyerapan informasi yang maksimal akan mempengaruhi hasil belajar. Pembelajaran yang sesuai dengan karakteristik gaya belajar siswa akan meningkatkan konsentrasi siswa dalam menyerap informasi.

\section{Hipotesis Ketiga}

Dari hasil pengujian hipotesis untuk interaksi antara model pembelajaran dengan gaya belajar, didapatkan nilai $F_{\text {hitung }}>F_{\text {tabel }}$ yakni 4,569 > 3,18 sehingga $\mathrm{H}_{03}$ ditolak dan $\mathrm{H}_{\mathrm{a} 3}$ diterima. Hal ini berarti terdapat interaksi antara model kooperatif tipe group investigation dengan gaya belajar terhadap hasil belajar fisika siswa. 
Model pembelajaran kooperatif tipe group investigation dan gaya belajar secara signifikan berpengaruh terhadap hasil belajar fisika siswa pada materi fluida statis dan diantara keduanya terdapat interaksi secara bersama-sama dalam mempengaruhi hasil belajar, karena kesimpulan yang didapatkan dari hasil uji anova dua arah ini masih terlalu umum maka analisis dilanjutkan dengan uji Scheffe untuk membandingkan nilai rata-rata dari tiap kelompok.

Dari grafik 3, juga terlihat siswa yang gaya belajarnya visual nilai rataratanya lebih tinggi dibanding siswa yang gaya belajar audio dan kinestetik, kemudian gaya belajar audio lebih tinggi dari gaya belajar kinestetik. Keadaan ini berlaku untuk kedua kelas baik eksperimen maupun kelas kontrol, tetapi terlihat perbedaan bahwa rata-rata nilai hasil belajar pada kelas eksperimen dengan model pembelajaran kooperatif tipe group investigation lebih tinggi untuk semua kategori gaya belajar dibandingkan dengan kelas kontrol dengan model pembelajaran konvensional. Hal ini membuktikan bahwa pemberian perlakuan dengan model pembelajaran kooperatif tipe group investigation lebih baik dibandingkan model pembelajaran konvensional dalam hal ini direct intraction.

Hasil penelitian ini didukung oleh hasil penelitian sebelumnya yang dilakukan oleh Halim (2012) yang menunjukkan bahwa terdapat interaksi antara strategi pembelajaran dan gaya belajar yang mempengaruhi hasil belajar IPA Fisika siswa. Selain itu, didukug juga oleh hasil penelitia 'Ardhuha, et al. (2016) yang meyimpulkan bahwa terdapat pengaruh interaksi sebesar $(50,2 \%)$ antara model pembelajaran dengan gaya belajar terhadap hasil belajar IPA Fisika siswa.

\section{PENUTUP}

Berdasarkan hasil penelitian dan pembahasan, maka dapat disimpulkan bahwa:

1. Terdapat pengaruh model pembelajaran kooperatif tipe group investigation terhadap hasil belajar fisika siswa pada materi fluida statis yaitu model pembelajaran group investigation memberikan pengaruh yang lebih baik dari pada model pembelajaran konvensional tehadap hasil belajar fisika siswa.

2. Terdapat pengaruh gaya belajar terhadap hasil belajar fisika siswa pada materi fluida statis. Hasil belajar fisika siswa berdasarkan gaya belajarnya memberikan hasil yang lebih baik secara berurutan dari yang lebih tinggi hingga terendah dimulai dari gaya belajar visual, audio dan disusul dengan gaya belajar kinestetik.

3. Terdapat interaksi antara model pembelajaran kooperatif tipe group investigation dengan gaya belajar terhadap hasil belajar fisika siswa pada materi fluida statis.

\section{REFERENSI}

'Ardhuha, J., dan Nurmayani, Syuaib, M. Z. 2016. Pengaruh Gaya Belajar VAK pada Penerapan Model Pembelajaran Problem Based Learning Terhadap Hasil Belajar IPA Fisika Siswa SMP Negeri 2 Narmada Tahun Ajaran 2015/2016. Jurnal Pendidikan Fisika dan Teknologi. 2 (1): 13-21.

Asyhar, R., dan Ernawati R., Sjarkawai. 2012. Pengaruh Penerapan Model Pembelajaran Kooperatif Tipe Group Investigation (GI) Terhadap Hasil Belajar dan Sikap Ilmiah Siswa pada Mata Pelajran Fisika SMA. Tecno-Pedagogi. 2 (2): 8092. 
Gunada, I. W., dan Sahidu, H., Sutrio, S. (2015). Pengembangan Perangkat Pembelajaran Fisika Berbasis Masalah untuk Meningkatkan Hasil Belajar dan Sikap Ilmiah Mahasiswa. Jurnal Pendidikan dan Teknologi. 1 (1): 38-46.

Gunawan, G., Sahidu, H., Harjono, A., \& Suranti, N. M. Y. The Effect of Project Based Learning with Virtual Media Assistance on Student's Creativity in Physics. Cakrawala Pendidikan, (2), 167-179.

Halim, A. 2012. Pengaruh Strategi Pembelajaran dan Gaya Belajar terhadap Hasil Belajar Fisika Siswa SMPN 2 Secanggang Kabupaten Langkat. Jurnal Tabularasa PPS Unimed. 9 (2): 141-158.

Hariyanto dan Suyono. 2011. Belajar dan Pembelajaran Teori dan Konsep Dasar. Bandung: Rosda.

Nisrina, N., Gunawan, G., \& Harjono, A. (2016). Pembelajaran Kooperatif dengan Media Virtual untuk Peningkatan Penguasaan Konsep Fluida Statis Siswa. Jurnal Pendidikan Fisika dan Teknologi, 2(2), 66-72.

Pujani, M, dan Restami, M. P, Suma, K. 2013. Pengaruh Model Pembelajaran POE (PredictObserve-Explain) terhadap Pemahaman Konsep Fisika dan Sikap Ilmiah Ditinjau dari Gaya Belajar Siswa. E-Journal Program Pascasarjana Universitas Pendidikan Ganesha Program studi IPA. Vol 3: 1-11.

Rahmatullah, Sahidu, H., Ayub, S. 2017. Pengaruh Model Pembelajaran Kooperatif Tipe Group Investigation (GI) dengan Teknik Open-Ended Problem Terhadap Aktivitas dan Hasil Belajar Fisika Siswa SMAN 3 Mataram. Jurnal Pendidikan Fisika dan Teknologi. 3 (2): 109-118.

Suparmi, dan Susilo, F., Sunarno, W. 2016. Pembelajaran Fisika Menggunakan
Model jigsaw dan GI (Group Investigation) Ditinjau dari Kreativitas dan Sikap Ilmiah Belajar Siswa. Jurnal Inkuiri. 5 (3): 40-48.

Tika I. N., dan Sudewi N. L., Subagia I. W. 2014. Studi Komparasi Penggunaan Model Pembelajaran Problem Based Learning (PBL) dan Kooperatif Tipe Group Investigation (GI) Terhadap Hasil Belajar Berdasarkan Taksonomi Bloom. E-Journal Program Pascasarjana Universitas Pendidikan Ganesha Program Studi IPA. 4.

Wahyuni, R., dan Hikmawati, Taufik, M. (2016). Pengaruh Model Pembelajaran Inkuiri Terbimbing dengan Metode Eksperimen terhadap Hasil Belajar Fisika Siswa Kelas XI IPA SMAN 2 Mataram Tahun Pelajaran 2016/2017. Jurnal Pendidikan Fisika dan Teknologi. 2 (4): 164-169. 